Exp. Anim. 38(3), 259-262, 1989

\title{
Reference Values of Hematological, Serum Biochemical and Hormonal Examinations in Female Cynomolgus Monkeys (Macaca fascicularis) of Feral Origin
}

\author{
Takashi YOSHIDA, Akimichi KATSUTA*, and Fumiaki CHO \\ Tsukuba Primate Center for Medical Science, The National Institute of Health, \\ Hachimandai, Tsukuba-shi, Itaraki 305, Japan and* The Industrial \\ Research Institute of Japan, Shinkawa, Chuo-ku, Tokyo 104.
}

(Received 8 November 1988/Accepted 28 February 1989)

\begin{abstract}
Blood samples were collected from clinically healthy female cynomolgus monkeys imported from Indonesia, the Philippines and Malaysia. These animals were maintained under uniform environmental conditions for four to five years. The blood samples were examined for their hematological, serum biochemical and hormonal values. The ranges of the values as well as their arithmetic means and standard deviations have been tabulated with respect to each examination item.
\end{abstract}

Interest in biomedical use of nonhuman primate species has recently been increasing. We have established a breeding colony of cynomolgus monkey (Macaca fascicularis) for the purpose of using this species as a laboratory animal $[1,2]$. However, it is currently rather difficult to use the laboratory-bred monkeys for experiments, since their availability is still quite limited. Therefore, the value of wildimported monkeys is still high, and reference values for their hematological, serum biochemical and endocrinological examinations are needed. Although some reference values of serum chemistry for cynomolgus monkeys have been reported previously $[5,6,9]$, useful and practical reference values have remained more or less lacking with regard to clinical biochemistry and endocrinology as the determination of baseline data is of ten laborious and costly.

At Tsukuba Primate Center for Medical Science (TPC), the National Institute of Health, Japan, a female cynomolgus monkey population of feral origin is being maintained in large under uniform environmental conditions. This population provides a valuable resource for the determination of reference values. Therefore, it was our objective to obtain hematological, serum biochemical and endocrinological values employing this population.

The cynomolgus monkeys used in this study were imported from Indonesia, the Philippines and Malaysia. They were raised and maintained for four to five years in individual cages $(45 \times 60 \times 60 \mathrm{~cm})$ set in animal rooms, with a room temperature of $25 \pm 2{ }^{\circ} \mathrm{C}$, a relative humidity of $60 \pm 5 \%$, a light and dark cycle of $14 \mathrm{~L} 10 \mathrm{D}$, and fresh air changes of 10 times per hour. Every day the animals were fed with about $100 \mathrm{~g}$ of apples and oranges in the morning, and about $70 \mathrm{~g}$ of a commercially-prepared monkey diet (Type AS, Oriental Yeast Co., Ltd. Tokyo) in the evening. These animals were estimated to be more than five years old, based on the dental examination at the time of importation and had been reared under uniform environmental conditions at TPC. No animal showed any sign of clinical disorder and any sign of pregnancy at the time of blood sampling. Food was withheld for at least 16 hour prior to each sampling. Blood samples were drawn between 0930 and 1100. For this investigation, 312 animals were used and the mean body weight, standard deviation on the day of sampling were $3.56 \pm 0.96 \mathrm{~kg}$ in a range of 1.75 to $7.25 \mathrm{~kg}$. The monkeys were sedated 
Table 1. Test methods used to establish reference values

\begin{tabular}{|c|c|}
\hline Test & Method \\
\hline Red blood cells & Microcell counter ${ }^{\mathrm{a}}$ \\
\hline Hematocrit & Microcell counter ${ }^{\mathrm{a}}$ \\
\hline Hemoglobin & Cyanomethemoglobin ${ }^{a}$ \\
\hline Mean cell volume & Microcell counter ${ }^{\mathrm{a}}$ \\
\hline White blood cells & Microcell counter ${ }^{\mathrm{a}}$ \\
\hline Glutamic oxaloacetic transaminase & $\mathrm{NADH} \cdot \mathrm{NAD}$ \\
\hline Glutamic pyruvic transaminase & NADH-NAD \\
\hline Total protein & Biuret $^{\mathrm{b}}$ \\
\hline Albumin & Bromcresol green ${ }^{\mathrm{b}}$ \\
\hline Albumin-globulin ratio & Calculated ${ }^{\mathrm{b}}$ \\
\hline Blood urea nitrogen & Urease $^{\mathrm{b}}$ \\
\hline Glucose & Glucose oxidase $^{\mathrm{b}}$ \\
\hline Total cholesterol & Enzymatic ${ }^{b}$ \\
\hline Free cholesterol & Enzymatic ${ }^{\mathrm{b}}$ \\
\hline High density lipoprotein cholesterol & Enzymatic ${ }^{b}$ \\
\hline Phospholipids & Enzymatic ${ }^{\mathrm{b}}$ \\
\hline Free fatty acids & Enzymatic $^{\mathrm{b}}$ \\
\hline Uric acid & Enzymatic $^{\mathrm{b}}$ \\
\hline Triglycerides & Enzymatic $^{\mathrm{b}}$ \\
\hline Thymol turbidity test & Thymol reaction ${ }^{\mathrm{b}}$ \\
\hline Alkaline phosphatase & p-Nitrophenyl phosphate hydrolysis \\
\hline Alcohol dehydrogenase & Alcohol substrate \\
\hline$\gamma$-Glutamyl transpeptidase & $\gamma$-Glutamyl-p-nitroanilide substrate ${ }^{\mathrm{b}}$ \\
\hline Lactate dehydrogenase & $\mathrm{NADH} \cdot \mathrm{NAD}^{\mathrm{b}}$ \\
\hline Amylase & Enzymatic $^{\mathrm{b}}$ \\
\hline Creatinine & Kinetic Jaffe $\mathrm{e}^{\mathrm{b}}$ \\
\hline Sodium & Flame emission spectrophotometry ${ }^{c}$ \\
\hline Potassium & Flame emission spectrophotometry \\
\hline Calcium & Flame photometry \\
\hline Cortisol & Radioimmunoassay ${ }^{\mathbf{e}}$ \\
\hline Renin & Radioimmunoassay ${ }^{f}$ \\
\hline Angiotensin-I & Radioimmunoassay ${ }^{f}$ \\
\hline Insulin & Enzymeimmunoassay $^{9}$ \\
\hline
\end{tabular}

a : CC-108, 110, MH-301, Toa Medical Electronics Co., Ltd. b : 706, Hitachi Ltd. c: AA275, Varian-Techtron Co., Ltd. d:Flame-30 C, Nippon Bunkoh Medical Co., Ltd. e : Spac Cortisol kit II, Daiichi Radioisotope Labs., Ltd. f : Renin Riabead,

Dainabot Co., Ltd. g : Insulin EIA kit, Kainos Labs. Inc.

with intramuscular injection of ketamine hydrochloride (Ketalar 50, Park Davis-Sankyo Co., Ltd. Tokyo) with the dosage of approximately $5 \mathrm{mg} / \mathrm{kg}$ body weight. Samples were taken by femoral vein puncture. Two $\mathrm{ml}$ of blood were collected in a vacuum blood collection tube containig EDTA-2 $\mathrm{Na}$ as anticoagulant for hematological measurement that were performed on the day of blood withdrawal. In additino, $5 \mathrm{ml}$ were collected in a tube without anti-coagulant for serum biochemical and endocrinological measurements. Serum samples were separated by centrifugation and divided into two aliquots, one of which was stored at $4^{\circ} \mathrm{C}$ for serum biochemical measurements performed on the day after the blood sampling, and the other aliquot was stored at $-80^{\circ} \mathrm{C}$ until use for hormone assays.

The measurement items and analytical methods are summarized in Table 1 . Prior to measurement of the present blood samples, both the accuracy and precision of each measuring procedure were examined. The coefficients of variations of hematological and serum biochemical tests ranged from $0.8 \%$ to $3.8 \%$ between assays (Cellcheck-400, Toa Medical Electronics Co., Ltd. Kobe, Beckman Decision Multilevel Comprehensive Chemistry Control Serum, Beckman Instruments. Tokyo). The coefficients of variation of the radioimmunoassays (RIAs) and of the enzymeimmunoassay (EIA) were less than $5 \%$ wihin assay and 
Table 2. Blood and serum values of adult female cynomolgus monkeys of feral origin, showing sample size ( $\mathrm{n})$, Mean (x), Standard deviation (SD) and observed range $(O$. R.) for each value

\begin{tabular}{|c|c|c|c|c|c|c|c|}
\hline Test & Unit & $\mathrm{n}$ & $\mathrm{x}$ & $\mathrm{SD}$ & Min. & O. R. & Max. \\
\hline Red blood cells & $\times 10^{4}$ cell $\mathrm{s} / \mathrm{mm}^{3}$ & 300 & 608 & 63 & 418 & - & 776 \\
\hline Hematocrit & percent & 309 & 40.8 & 4.5 & 30.2 & - & 53.3 \\
\hline Hemoglobin & $\mathrm{g} / \mathrm{d} \ell$ & 301 & 11.3 & 1.3 & 8.1 & - & 14.7 \\
\hline Mean cell volume & $\mathrm{fl}$ & 306 & 67 & 5 & 56 & - & 88 \\
\hline White blood cells & $\times 10^{3}$ cell s $/ \mathrm{mm}^{3}$ & 302 & 9.7 & 2.8 & 4.5 & - & 19.4 \\
\hline Glutamic oxaloacetic transaminase & Karmen units & 297 & 29.5 & 7.8 & 11.0 & - & 75.0 \\
\hline Glutamic pyruvic transaminase & Karmen units & 298 & 31.7 & 15.7 & 6.0 & - & 95.0 \\
\hline Total protein & $\mathrm{g} / \mathrm{d} \ell$ & 307 & 8.25 & 0.69 & 6.71 & - & 9.95 \\
\hline Albumin & $\mathrm{g} / \mathrm{d} \ell$ & 291 & 4.05 & 0.20 & 3.02 & - & 4.70 \\
\hline Albumin-globulin ratio & & 310 & 0.97 & 0.15 & 0.69 & - & 1.33 \\
\hline Blood urea nitrogen & $\mathrm{mg} / \mathrm{d} \ell$ & 308 & 15.1 & 3.8 & 7.2 & - & 23.4 \\
\hline Glucose & $\mathrm{mg} / \mathrm{d} \ell$ & 278 & 44 & 12 & 14 & - & 96 \\
\hline Total cholesterol & $\mathrm{mg} / \mathrm{d} \ell$ & 301 & 120 & 27 & 62 & - & 201 \\
\hline Free cholesterol & $\mathrm{mg} / \mathrm{d} \ell$ & 293 & 21 & 6 & 6 & - & 50 \\
\hline High density lipoprotein cholesterol & $\mathrm{mg} / \mathrm{d} \ell$ & 30 & 56 & 27 & 19 & - & 145 \\
\hline Phospholipids & $\mathrm{mg} / \mathrm{d} \ell$ & 30 & 181 & 42 & 111 & - & 300 \\
\hline Free fatty acids & $\mathrm{mEq} / \ell$ & 30 & 0.89 & 0.41 & 0.34 & - & 2.08 \\
\hline Uric acid & $\mathrm{mg} / \mathrm{d} \ell$ & 30 & 0.65 & 0.44 & 0.4 & - & 2.3 \\
\hline Triglycerides & $\mathrm{mg} / \mathrm{d} \ell$ & 312 & 58 & 22 & 15 & - & 116 \\
\hline Thymol turbidity test & Kunkel units & 82 & 0.8 & 0.6 & 0 & - & 1.8 \\
\hline Alkaline phosphatase & King-Armstrong units & 258 & 8.6 & 2.3 & 2.8 & - & 49.6 \\
\hline Alcohol dehydrogenase & $\mathrm{IU} / \ell$ & 196 & 1.39 & 0.78 & 0.16 & - & 3.65 \\
\hline$\gamma$-Glutamyltranspeptidase & $\mathrm{IU} / \ell$ & 194 & 65 & 21 & 19 & - & 116 \\
\hline Lactate dehydrogenase & $\mathrm{IU} / \ell$ & 198 & 563 & 218 & 95 & - & 997 \\
\hline Amylase & $\mathrm{IU} / \ell$ & 198 & 713 & 213 & 300 & - & 1170 \\
\hline Creatinine & $\mathrm{mg} / \mathrm{d} \ell$ & 183 & 1.1 & 0.2 & 0.6 & - & 2.1 \\
\hline Sodium & $\mathrm{mEq} / \ell$ & 190 & 160 & 6 & 140 & - & 177 \\
\hline Potassium & $\mathrm{mEq} / \ell$ & 180 & 5.8 & 0.7 & 4.2 & - & 9.0 \\
\hline Calcium & $\mathrm{mEq} / \ell$ & 181 & 10.1 & 0.4 & 8.4 & - & 11.5 \\
\hline Cortisol & $\mu \mathrm{g} / \mathrm{d} \ell$ & 120 & 6.23 & 0.12 & 2.75 & - & 9.17 \\
\hline Renin & $\mathrm{ng} / \mathrm{m} \ell / \mathrm{hr}$ & 107 & 7.6 & 4.5 & 1 & - & 24 \\
\hline Angiotensin-I & $\mathrm{ng} / \mathrm{m} \ell$ & 107 & 0.27 & 0.33 & 0.1 & - & 1.8 \\
\hline Insulin & $\mu \mathrm{U} / \mathrm{m} \ell$ & 126 & 41 & 31 & 2 & - & 183 \\
\hline
\end{tabular}

less than $10 \%$ between assays.

Mean values for female cynomolguis monkeys are presented in Table 2 . No remarkable relation between each value and the phase of menstrual cycle of each monkey was observed.

It has already been reported that human RIAs and EIAs were available for measuring serum concentrations of cynomolgus monkey insulin [8]. Serum concentrations of angioten sin-I in cynomolgus monkey were measured by a human EIA kit. It is well known that an antihuman angiotensin-I usually has crossreactivity to angiotensin-I from many mammalian species, such as equines, dogs, pigs and rats [7]. We employed a human angiotensin-I RIA kit to measure serum levels of angiotenisin-I in cynomolgus monkey.
Concerning reference values for serum biochemistry in the cynomolgus monkey, several papers have been published. However, the number of animals used for these studies was not large enough. Even in the largest-scale study in previous papers, only about thirty animals per group were used $[3,4,9]$. In the present study, at least, thirty animals were used for each test even on the smallest scale. Because of the lack of seasonal variation in the feeding conditions for our cynomolgus monkeys, we processed our data collectively without regard to the season of the blood sampling. The maximum number of animals used in the present study reached more than three hundred in some items. This number is seemed to be satisfactory enough to determine 
the reference range of the cynomolgus monkey. We already reported that the hematological and serum biochemical values of laboratorybred monkeys [10]. The laboratory-bred female cynomolgus monkeys aged over 10 years showed the higher values in mean cell volume, albumin, albumin-globulin ratio, Triglycerides and lower values in total protein than those of the wild-imported monkeys examined in this study. The difference of blood and serum properties between laboratorybred animals and wildimported animals should be further examined. As conclusion, the present reference values should prove useful to those who wish to use cynomolgus monkeys of feral origin as experimental animals.

We are grateful to many people at Tsukuba Primate Center for their collaboration in this study. We are indebted to Mrs. Kinue Suzuki and Mrs. Keiko Ohtoh for their excellent technical assistance. We wish to express our thanks to Dr. Shigeo Honjo for his suggestions and for his help in the preparation of this manuscript. Part of this work was undertaken as a research project for the Agency of Natural Resources and Energy, Ministry of International Trade and Industry, Japan, entitied "Toxi- cological Research of Methanol as Fuel for Power Station"

\section{References}

[1] Honjo, S., Cho, F., and Terao, K. (1984). Advances. In Veterinary Science and Companative Medicine. pp. 51-80. Vol. 28, Hendrickx (edit.), Academic Press, New York.

[2] Honjo, S. (1985). J. Med. Primatol, 14, 75-89.

[3] Kapeghian, J. C. and Verlangieri, A. J. (1984). J. Med. Primatol, 13, 97-107.

[4] Kapeghian J. C., Bush, M. J., and Verlangieri, A. J. (1984). J. Med. Primatol, 13, 283-288.

[5] Kawanishi, Y., Cho, F., and Honjo, S. (1973). Japan. J. Med. Sci Biol, 26, 249-260.

[6] Matsumoto, K., Akagi, H., Ochiai, T., Hagino, K., Sekita, K., Kawasaki, Y., Matin, M. A., and Furuya, T. (1980). Exp. Animals., 29, 335-340.

[7] Nishimura, H. (1980). In The Renin-Angiotensin System, pp. 29-74, Johnson, J. A. and Anderson, R. R. (edit.), Plenum Press, New York.

[8] Sakurai, T., Katsuta, A., and Yoshida, T. (1988). Exp. Anim, 37, 53-58 (Text in Japanese).

[9] Verlangieri, A. J., DePriest, J. C.., and Kapeghian, J. C. (1985). Lab. Anim Sci 35, 63-66.

[10] Yoshida, T., Suzuki, K., Cho, F.,and Honjo, S. (1986). Exp. Anim., 35, 329-338 (Text in Japanese).

\title{
野生由来メス・カニクイザル (Macaca fascicularis) の血液学的, 血清生化学的拈よび内分泌学的測定值
}

\author{
吉田高志・勝田晨陸* ・長 文昭 \\ 国立予防衛生研究所筑波医学実験用霊長類センター \\ *財団法人工業開発研究所
}

野生由来メス・カニクイザルを用いて，血液学的（15 項目), 血清生化学的 (24項目), および内分泌学的 (4 項目）測定を実施した。対象とした動物は, 東南アジア より輸入され, 当センターに入荷してから 4 年ないし 5
年間, 個別ケージで飼育されたるのである。使用頭数 は, 測定項目によって異なるが, 最少 30 頭, 最大 312 頭 である。本研究によって, 野生由来メス・カニクイザル の参考値を提供することができたものと判断される。 